\title{
Transient Remission after Intercurrent Measles Infection in a Patient with Hyperimmunoglobulin E Syndrome
}

\author{
CHING-YUANG LIN \\ The Pediatric Research Laboratory, Department of Medical Research and Pediatrics, Veterans General Hospital \\ Hospital, Taiwan, Republic of China
}

\begin{abstract}
A 5-yr-old patient with hyper IgE syndrome contracted measles. This was accompanied by a temporary disappearance of his skin lesions. The patient had a long history of recurrent infections, chronic eczematoid pruritic dermatitis, and elevation of serum IgE level since infancy. Immunologic studies revealed decreased suppressor $T$ cells (OKT8 cells) with increased IKT4/OKT8 ratio, defect in suppressor $\mathrm{T}$ cell function, and decreased chemotactic index. In February 1985, when he developed an interrcurrent measles infection at age of 5 , the eczematoid pruritic dermatitis disappeared completely and immunologic defects improved transiently, with normalization of OKT4/ OKT8 ratio, decrease in in vitro IgE synthesis, in vivo serum IgE level, and interleukin-2 production, decreases in $\mathrm{IgG} \mathrm{Fc}$ receptor-bearing cells and autologous mixed lymphocyte reaction, and normalization of chemotactic index. One month later, the eczematoid skin lesion relapsed and immunologic defects reappeared. These studies suggested that the pathogenesis of hyper IgE syndrome involved a hypofunction of suppressor $T$ cell. The transient remission associated with measles infection is probably related to the effect of the virus on the helper $T$ cells, resulting in a normalization of OKT4/OKT8 ratio and IgE production. (Pediatr Res 20: 685-688, 1986)
\end{abstract}

Abbreviation

IL-2, interleukin-2

The hyper IgE syndrome is characterized by recurrent staphylococcal abscesses of the skin, lungs, joints, and other sites, beginning in infancy; blood and tissue eosinophilia; and extremely elevated serum $\operatorname{IgE}$ concentration (1-5). Although all patients have had a pruritic dermatitis at some time in their lives, the distribution of the lesions is not typical for atopic dermatitis, and the respiratory allergic symptoms are usually absent $(1,4)$. The pathogenesis of this disease is unknown, but abnormal regulatory $\mathrm{T}$ cell functions $(1,2)$, defect of suppressor $\mathrm{T}$ cell function (6), and defect in in vivo and sometimes in vitro neutrophil chemotaxis (5) have been reported.

Natural measles infection can cause prolonged depression of cell-mediated immunity and induce remission of steroid-sensitive nephrotic syndrome (7-9). This has been attributed to the effects of measles virus on the immunologic system $(7,9)$. However, to our knowledge, a transient remission after measles

Received August 19, 1985; accepted January 23, 1986.

Address for correspondence Dr. Ching-Yuang Lin, Pediatric Research Laboratory, Department of Medical Research, Veterans General Hospital, Shih-Pai, Taipei, Taiwan, 11217, R.O.C. infection in patients with hyper IgE syndrome has not been reported. Therefore, we thought it worthwhile to report our experience with one patient with hyper IgE syndrome who experienced transient, but complete remission of the skin lesion, and dramatic improvement in immunologic abnormalities after intercurrent measles infection. In an attempt to elucidate the pathogenesis of hyper IgE syndrome and immunologic changes after measles infection, we measured $\mathrm{T}$ cell subpopulations, lymphoproliferative response, autologous mixed lymphocyte reaction, in vitro $\mathrm{IgE}$ synthesis, and chemotaxis in remission and during relapse.

\section{MATERIALS AND METHODS}

Total $\mathrm{T}$ lymphocytes (Total $\mathrm{T}$ cells) and $\mathrm{B}$ cells (fluorescent method) were prepared and detected according to the method of Kerman et al. (10) with slight modification (9). Phenotypic analysis of $T$ cell subpopulations were analyzed by indirect immunofluorescence using mouse monoclonal antibodies (9) (OKT4, OKT8, and OKIal antisera; Ortho Pharmaceutical Corporation). The lymphocytes bearing $\mathrm{IgG} \mathrm{Fc}$ receptors were detected according to the method of Thompson et al. (11) with rosette assay employing fixed ox erythrocytes coated with human $\lg G$.

Lymphoproliferative responses to phytohemagglutinin and measles antigen were measured as previously described (9). Briefly, lymphocytes were separated with Ficoll-Hypaque density gradient and cultured in $1 \times 10^{6} / \mathrm{ml}$ of RPMI 1640 on microtiter $\mathrm{U}$ plates containing $10 \%$ healthy control's $\mathrm{AB}$ serum and were calculated as count per minute.

Autologous mixed lymphocyte reaction was carried out as previously described (12). Briefly, $0.1 \mathrm{ml}$ of T lymphocyte suspension was mixed with $0.1 \mathrm{ml}$ of $\mathrm{B}$ cell and monocyte suspension and then cultured in round-bottom microtiter plates (Flow Laboratories) for 7 days in a humidified $5 \% \mathrm{CO}_{2}, 37^{\circ} \mathrm{C}$ incubator. The B cells and monocytes were pretreated with $50 \mu \mathrm{g} / \mathrm{ml}$ of mitomycin $\mathrm{C}$ for $30 \mathrm{~min}$ at $37^{\circ} \mathrm{C}$. Twenty $\mathrm{h}$ before the end of culture, $1 \mu \mathrm{Ci} \mathrm{H}^{3}$-thymidine (New England Nuclear, Boston, MA, specificity $6.7 \mathrm{Ci} / \mathrm{mM}$ ) in $20 \mu \mathrm{l}$ RPMI 1640 was added to the cultures. The cells were harvested by an automatic harvester and the radioactivity was counted. Stimulation index was calculated by dividing the cpm of stimulated culture by that of unstimulated counterpart.

Complement-dependent lysis of $T$ cell subsets was carried out using 20 million T lymphocytes suspended in $0.8 \mathrm{ml}$ of a $1: 250$ dilution of anti-OKT8 or anti-OKT4 antibody in phosphatebuffered saline and incubated for $1 \mathrm{~h}$ at room temperature. Then $0.2 \mathrm{ml}$ rabbit complement (Pel-Freeze Biological Inc, Rogers, AR) was added and the suspension was incubated for an additional $60 \mathrm{~min}$ at $37^{\circ} \mathrm{C}$. Immunofluorescence of the lymphocytes before and after treatment with anti-OKT8 or anti-OKT4 anti- 
body and complement demonstrated complete ( $>98 \%$ ) removal of the corresponding $T$ cell subset from the cell suspension.

The effect of normal control cells on in vitro IgE synthesis by the patient's lymphocyte subsets was assessed by coculture technique. $\mathrm{T}$ lymphocytes were separated from mononuclear cells after Ficoll-Hypaque gradient by rosetting first with neuraminidase-treated sheep erythrocytes overnight in ice water and then centrifuging over Ficoll-Hypaque density gradient. The interphase cell which contained $40-47 \% \operatorname{sig}(+)$ lymphocytes were designated as B lymphocyte-enriched population. Normal control T8, T4 cells were match mixed with patient's T8, T4 cells in a 1:1 ratio and cultured at a concentration of $1 \times 10^{6}$ cells $/ \mathrm{ml}$ in a final volume of $1 \mathrm{ml} /$ culture. The value of $\operatorname{IgE}$ observed in the supernatant of mixed cell culture was measured at the end of the 6 day culture period by using Phadebas IgE PRIST Kits (Pharmacia, Sweden).

The production of interleukin-2 (IL-2) from patient's MNC was induced by the $1 \mu \mathrm{g} / \mathrm{ml}$ phytohemagglutinin and $5 \mathrm{ng} / \mathrm{ml}$ of phorbol myristic acetate (P8139, Sigma). After $48 \mathrm{~h}$ of incubation at $37^{\circ} \mathrm{C}$ and $7 \% \mathrm{CO}_{2}$, supernatant was collected by centrifugation. The cell line used to detect the presence of IL-2 was CTLL2 (13).

The measurement of $\mathrm{IL}-2$ receptor (Tac) was carried out by indirect immunofluorescence using monoclonal antibody before and after 3 days of measles antigen stimulation.

Delayed type hypersensitivity skin test to PPD was read after $48 \mathrm{~h}$; and induration with diameter greater than $5 \mathrm{~mm}$ was considered positive.

The inhibition of macrophage migration was determined by employing indirect agarose method as described previously (9), measles antigen was employed in a concentrations of $0.02 \mathrm{ml}$ of preservative-free stock solution per $\mathrm{ml}$ of phosphate buffer solution. Twenty healthy children who had a positive skin test to PPD and measles vaccination were selected as control.

The patient's macrophage and neutrophil chemotactic activities were performed as described by Ward (14) and others (12). The chemotactic index was calculated by the following formula:

\section{cells that migrated with $\mathrm{C} 5$ chemotactic fragment} cells that migrated with medium

Briefly, measles virus (Edmonston strain B) was grown in Vero cells, purified by two cycles of sucrose gradient centrifugation at $100,000 \times g$ for $2 \mathrm{~h}$. The supernatant was inactivated by heating at $56^{\circ} \mathrm{C}$ for $45 \mathrm{~min}$ and dialyzed against PBS to a final concentration of $200 \mu \mathrm{g}$ protein $/ \mathrm{ml}$ determined according to Lowry et al.

Ten normal, healthy, age- and sex-matched children were included in the control group.

\section{CASE REPORT}

A 5-yr-old Chinese boy had a long history of recurrent staphylococcal skin abscesses and eczematoid eruption since the 1st month of life. As an infant he developed recurrent sinusitis, pneumonia, and otitis media in February 1980. He was first admitted to a hospital with the chief problems of oral thrush pneumonia, eczematoid lesions, and pustules over the extremities, face, and trunk. Skin cultures yielded coagulase-positive Staphylococcus aureus and oral scrapings grew Candida albicans, which responsed to oxacillin and nystatin, respectively. At age of $2 \mathrm{yr}$, he was afflicted with pneumatocele after recurrent staphylococcal pneumonia. At age of 3 , he developed severe eczema herpeticum caused by herpes simplex type 1 infection requiring systemic acyclovir treatment. There was no adverse reaction observed following routine immunizations. His father had allergic rhinitis, but his mother and three sisters were healthy. Laboratory investigations revealed normal hemograms except for an intermittent eosinophilia which fluctuated between 15 and $30 \%$. Quantitative Ig determination revealed mild elevation in $\operatorname{IgG}(1600 \mathrm{mg} / \mathrm{dl}), \operatorname{IgA}(120 \mathrm{mg} / \mathrm{dl})$, and $\operatorname{IgM}(130 \mathrm{mg} / \mathrm{dl})$
The serum IgE ranged from 6,000 to $12,000 \mathrm{U} / \mathrm{ml}$. Serum C3, $\mathrm{C} 4$, and $\mathrm{CH}_{50}$ were normal. The $\mathrm{T}$ cell, $\mathrm{T}$ cell subsets, cellular immunity studies, and chemotactic index are shown in table 1 . Nitroblue tetrazolium test was $24 \%$ in unstimulated state. On February 2, 1985 he developed generalized eczematoid lesions and pustules over the face, trunk, and extremities (Fig 1a). He had come into contact with a measles patient on that day. One week later, he developed fever, conjunctivitis, and coryza. Two days later, the eczematoid lesions and pustules completely disappeared without any medication (Fig $1 b$ ), a situation which had never occurred during the past $5 \mathrm{yr}$ ). A maculopapular rash appeared from the head extending to the trunk and limbs. One week after this episode, the maculopapular rash disappeared with normal skin appearance (Fig $1 b$ ). However, eczematoid skin lesions with pustules developed again 1 month later.

Measles virus serology was performed before and after this episode and an increase in measles antibody titer (rising from 1:2 to $1: 128$ of complement-fixation antibody titer was detected), compatible with a recent measles infection. Blood chemistry including renal and liver functions remained within normal limits. The data of immunologic studies during this spontaneous remission of the long standing eczematoid skin lesions associated with measles infection and relapse are summarized in the Tables 1 and 2 .

\section{RESULTS}

Immunologic profile. BCG vaccination is used for prophylaxis against tuberculous infection in our country. Delayed type hypersensitivity skin tests to PPD (1TU, 5TU, 200TU) were negative during acute measles infection, but became positive 1 month later.

The profiles of lymphocyte subsets, lymphoproliferative response, autologous mixed lymphocyte reaction, and lymphokine production studies in this patient during acute measles infection and relapse of skin lesion are as shown in Table 1. Total white cell count and absolute lymphocyte count decreased in number during the acute measles infection, but returned to the normal range $4 \mathrm{wk}$ later. The same changes were noted also in the OKT4 cells, OKT8 cells, OKIal cells, total T and B cells. Whereas the OKT4/OKT8 ratio returned to normal range during measles infection, but decreased again 4 wk later. The IgG Fc receptorbearing cells was within normal range, but increased again $4 \mathrm{wk}$ later.

During the acute measles infection, lymphocyte proliferative response, IL-2 receptor and IL-2 production were significantly lower in lymphocytes cultured with either phytohemagglutinin or measles antigen. In the relapse of skin lesions, these returned to normal.

This was also true for leukocyte migration index to measles antigen during measles infection was $92 \%$, higher than that (> $80 \%$ ) of healthy controls. One month later, this index became normal.

In vitro synthesis of $\operatorname{IgE}$. As shown in table $2, \operatorname{IgE}$ production became normal ( $240 \mathrm{pg} /$ culture) during the measles infection, but markedly increased ( $2600 \mathrm{pg} /$ culture $) 1$ month later. When the patient's peripheral OKT8 cells were present in the coculture, a significantly increased IgE secretion was obtained. However, the patient's OKT4-enriched cells could not enhance IgE synthesis by the patient's B cell. During the measles infection the response did not differ from that of normal control. However, overproduction of IgE developed again in relapse of the skin lesions.

Serial determinations of in vitro neutrophil chemotaxis were performed, but the results were variable and the chemotactic defects did not correlate to the presence or absence of infection.

\section{DISCUSSION}

Janeway et al. (7), Blumberg and Cassady (8), and our group (15) have demonstrated spontaneous remission of nephrosis after 
Table 1. Immunologic parameters before, during, and in relapse after measles infection

\begin{tabular}{|c|c|c|c|c|}
\hline & $\begin{array}{c}\text { Before measles } \\
\text { infection }\end{array}$ & $\begin{array}{l}\text { In remission } \\
\text { during measles }\end{array}$ & $\begin{array}{c}\text { In relapse } \\
\text { after measles* }\end{array}$ & $\begin{array}{l}\text { Controls } \\
(n=10)\end{array}$ \\
\hline Absolute lymphocyte count $\left(/ \mathrm{mm}^{3}\right)$ & 3860 & 1366 & 4400 & $3414 \pm 864 / \mathrm{mm}^{3}$ \\
\hline Total T cell $\left(/ \mathrm{mm}^{3}\right)$ & 2316 & 614 & 2728 & $2642.2 \pm 428.4 / \mathrm{mm}^{3}$ \\
\hline OKT4 cell $\left(/ \mathrm{mm}^{3}\right)$ & 1737 & 491 & 2024 & $1702.6 \pm 244.4 / \mathrm{mm}^{3}$ \\
\hline OKT8 cell $\left(/ \mathrm{mm}^{3}\right)$ & 617 & 273 & 792 & $962.5 \pm 262.4 / \mathrm{mm}^{3}$ \\
\hline B cell $\left(/ \mathrm{mm}^{3}\right)$ & 501 & 109 & 528 & $866.4 \pm 125.6 / \mathrm{mm}^{3}$ \\
\hline OKIal cell $\left(/ \mathrm{mm}^{3}\right)$ & 656 & 40 & 660 & $526.4 \pm 106.8 / \mathrm{mm}^{3}$ \\
\hline Serum IgE $(\mathrm{U} / \mathrm{ml})$ & $6,000-12,000$ & 840 & 6700 & $<250$ \\
\hline \multicolumn{5}{|l|}{ Lymphoproliferative response to } \\
\hline Phytohemagglutinin $(5 \mu \mathrm{g} / \mathrm{ml})(\triangle \mathrm{cpm})$ & 114724 & 69320 & 106617 & $122068 \pm 47055$ \\
\hline measles antigen $(\triangle \mathrm{cpm})$ & $\mathrm{ND} \dagger$ & 44364 & 103214 & $104368 \pm 32062$ \\
\hline IL-2 production $(\mathrm{U} / \mathrm{ml})$ & ND & 16.2 & 120.4 & $44.6 \pm 4.4$ \\
\hline \multicolumn{5}{|l|}{ IL-2 receptor (Tac) } \\
\hline (with measles antigen) & ND & $16 \%$ & $67 \%$ & $62.4 \pm 8.6 \%$ \\
\hline MIF (measles antigen) & ND & $92 \%$ & $70 \%$ & $<80 \%$ \\
\hline \multicolumn{5}{|l|}{ AMLR: $T$ cell response to } \\
\hline $\mathrm{T}(\triangle \mathrm{cpm})$ & 1410 & 15524 & 1777 & $9548 \pm 3642$ \\
\hline B cell (stimulation index) & 0.17 & 1.22 & 0.33 & $1.84 \pm 1.42$ \\
\hline monocyte (stimulation index) & 0.21 & 0.85 & 0.36 & $1.21 \pm 0.42$ \\
\hline Chemotaxis index & 0.90 & 1.32 & 0.92 & $1.5 \pm 0.2$ \\
\hline
\end{tabular}

* In relapse performed 2 months later after measles infection. $\dagger$ Not done.

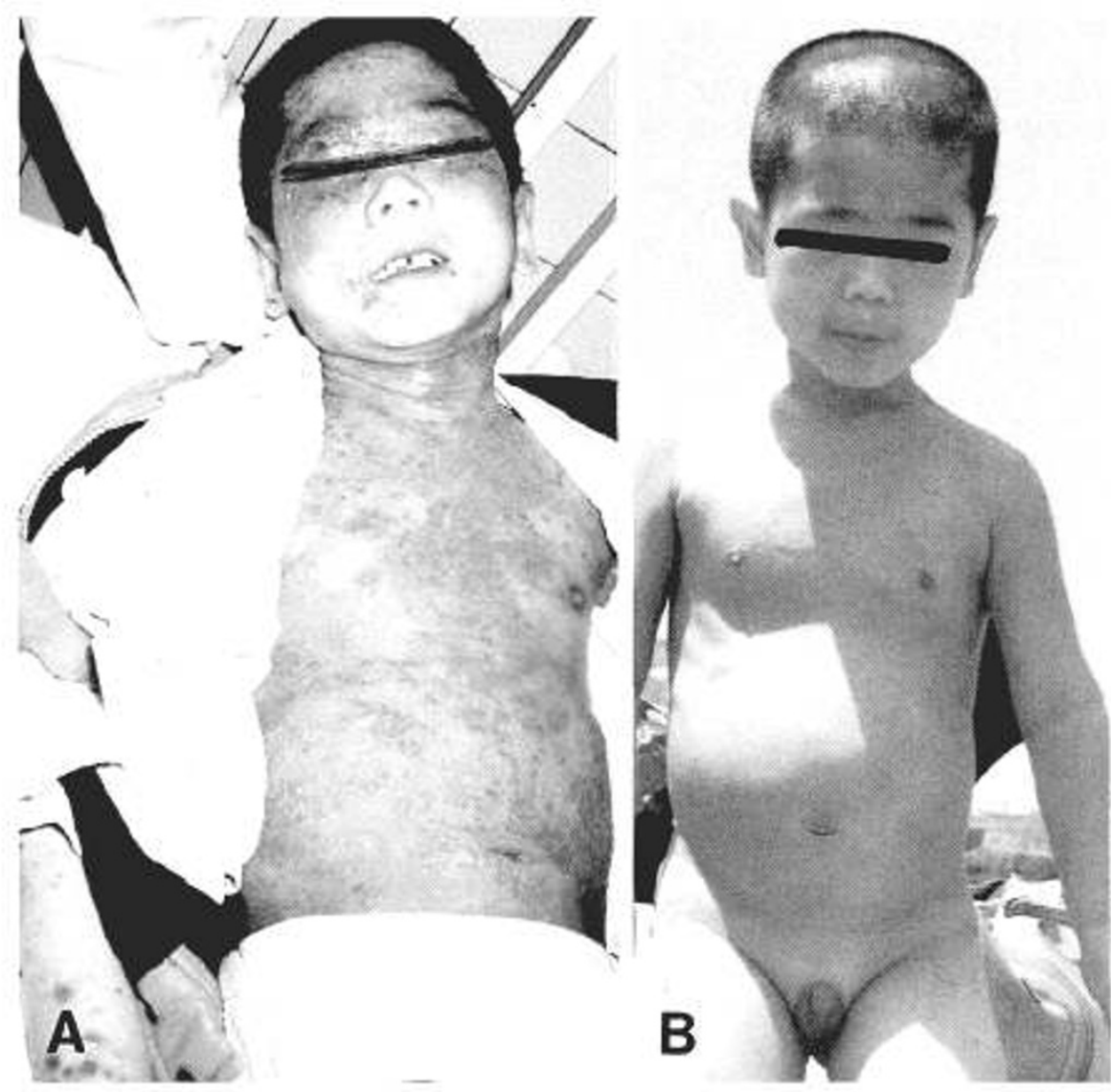

Fig. 1. $a$, the eczematoid lesions and pustules over face, trunk, and limbs were noted before measles infection. $b, 10$ days after contract with measles patient, his eczematoid lesions and pustules disappeared with some maculopapular measles' rash over the trunk.

intercurrent measles infection in children. The duration of the remission induced by measles varied from 1 to 7 months. However, there has been no report of transient improvement in both immunlogic and clinical features after measles infection in pa- tients with hyper IgE syndrome. The mechanism of measlesinduced remission is not clear, but the effects of measles virus on the immunologic system may play a role (15). Natural measles infection is known to cause prolonged depression of cell-me- 
Table 2. In vitro IgE synthesis in cocultures of patient and healthy control cells during acute measles and in relapse

\begin{tabular}{lcc}
\hline & $\begin{array}{c}\text { In remission } \\
\text { IgE (pg/culture) }\end{array}$ & $\begin{array}{c}\text { In relapse } \\
\text { IgE (pg/culture) }\end{array}$ \\
\hline PT8 + PT4 + PB* & 240 & 2600 \\
PT8 + PT4 + NB & 200 & 1600 \\
NT8 + NT4 + NB & 100 & 100 \\
NT8 + NT4 + PB & 110 & 120 \\
PT8 + NT4 + PB & 220 & 1400 \\
PT4 + NT8 + PB & 90 & 110 \\
\hline
\end{tabular}

*P, patient; N, normal control; T8, OKT8 cells; T4, OKT4 cells: B, $\mathrm{B}$ cells.

diated immunity $(15,16)$, including a negative in vitro delayed type hypersensitivity skin test (16). The measles virus can also directly infect the lymphoid cells, as shown by the presence of measles virus in lymphocytes by immunofluorescence (17) and recovery of the virus (18) during the acute infection.

The immunologic defects that lead to the chronic infections and eczematoid lesion in the hyper IgE syndrome are not yet established. Geha et al. (6) suggest that a defect in number and function of suppressor $\mathrm{T}$ cells may be the primary factor in the regulation of $\mathrm{IgE}$ synthesis in the hyper $\operatorname{IgE}$ syndrome. In our case, the OKT 8 cells were decreased both before and in relapse. However, OKT4 cells markedly decreased resulting in normalization of the OKT4/OKT8 ratio during acute measles, accompanied by a decreased serum IgE level and the disappearance of the eczematoid skin lesions. These findings were in accord with mouse experiments, in which measles virus infection affects predominantly the helper $\mathrm{T}$ lymphocytes and mildly the B lymphocytes (19).

The in vitro overproduction of IgE from patient's lymphocytes before measles infection and during relapse appeared to correlate with the change of OKT 8 cells. The series of mixing experiments show that the in vitro IgE synthesis was significantly increased by patient's OKT 8 cells in coculture. In contrast, patient's OKT4 cells did not enhance IgE secretion either by the B cells of the patient or normal group. These phenomena disappeared during acute measles infection. These results suggest that the decrease in OKT8 suppressor cells and increase in OKT4/OKT8 ratio are related to the elevation of serum IgE.

Another interesting finding in this hyper IgE syndrome patient was the autologous mixed lymphocyte reaction results. We have demonstrated that the $\mathrm{T}$ cells response to the stimulation of autologous non-T cells in this patient was lower than normals, but became normal during measles infection. However, the mechanism for this change is not clear.

In summary, the reason why measles infection can induce transient spontaneous remission of clinical features of hyper IgE syndrome is probably related to the effect of the virus on the helper T cells, resulting in a normalization of OKT4/OKT8 ratio and $\operatorname{IgE}$ production. These clinical and immunological observations will be helpful in understanding the overproduction of $\operatorname{IgE}$ in these patients.
Acknowledgments. The author thanks professor Michiaki Takahashi, Department of Virology, Osaka University, Osaka, Japan for the kindly gift of specific measles antigen and Dr. Thomas A. Waldman, Chief of Metabolism Branch, NCI for the kindly gift of anti-Tac antigen antibody.

\section{REFERENCES}

1. Buckley RH, Wray BB, Belmaker EZ 1972 Extreme hyperimmunoglobulinemia $E$ and undue susceptibility to infection. Pediatrics 49:59-70

2. Buckley RH, Sampson HA 1981 The hyperimmunoglobulinemia E syndrome. In: Franklin EC (ed) Clinical Immunology Update. Elsevier North-Holland, New York, pp 147

3. Buckley RH 1983 Studies of Patients with severe cellular and humoral immunodeficiency diseases using monoclonal antibodies. In: Haynes BF, Eisenberth GS (eds) Monoclonal Antibodies: Probes for the Study of Autoimmunity and Immunodeficiency. Academic Press, San Diego, pp 83-95

4. Thompson LF, Spiegelberg HL, Buckley RH 1985 IgE Fc receptor positive $\Upsilon$ and $B$ lymphocytes in patients with the hyperIgE syndrome. Clin Exp Immunol 59:77-84

5. Soderberg-Warner M, Rice-Mendoza CA, Mendoza GR, Stiehm ER 1983 Neutrophil and $\mathrm{T}$ lymphocyte characteristics of two patients with hyperlgE syndrome. Pediatr Res 17:820-824

6. Geha RS, Reinherz E, Leung D, Mckee KT Jr, Schlossman S, Rosen FS 1981 Deficiency of suppressor $T$ cells in the hyperimmunoglobulin $E$ syndrome. J Clin Invest 68:783-791

7. Janeway CA, MoKK GH, Armstrong Jr SH, Wallace WM, Hallman N, Barness LA 1948 Diuresis in children with nephrosis. Comparison of response to injection of normal human serum albumin and to infection particularly measles. Trans Assoc Am Phys 61:108-111

8. Blumberg RW, Cassady HA 1974 Effect of measles on the nephrotic syndrome. Am J Dis Child 73:151-166

9. Lin CY, Hsu HC 1985 Histopathological and immunological studies in spontaneous remission of nephrotic syndrome after intercurrent measles infection. Nephron (in press)

10. Kerman R, Smith R, Ezdinli E 1976 Unification and Technique aspects of Total T, active T and B lymphocyte rosette assay. Immunol Commun 5:685691

11. Thompson LF, Mellon MH, Zeiger RS, Spiegelberg HL 1983 Characterization with monoclonal antibodies of $\mathrm{T}$ lymphocytes bearing Fc receptors for $\mathrm{IgE}$ ( $\mathrm{T}$ cells) and IgG (Tr cells) in atopic patients. J Immunol 131:2772-2776

12. Lin CY, Hsu HC 1984 Acute immune complex mediated glomerulonephritis in a chinese girl with Wiskott-Aldrich syndrome variant. Ann Allergy 53:7478

13. Kappler JW, Skidmore B, White J, Marrack P 1981 Antigen-inducible, H-2 restricted, interleukin-2-producing T cells hybridomas. J Exp Med 153:1 1981214

14. Ward PA 1976 In: Rose NR, Friedman H (eds) Manual of Clinical Immunology. American Society for Microbiology, Washington, DC, p 106

15. Lin CY, Hsu HC, Hung HY 1985 Nephrotic syndrome associated with varicella infection. Pediatrics 75:1127-1131

16. Von Pirquet $C 1908$ Das verhalten der Kutamen Tuberkulin-reaction Wahrend der Masern. Dtsch Med Wochenschr 34:1297-1300

17. Osunkoya BO, Adeleye GL, Adejumo TA, Salimonu LS 1974 Studies in measles. Il. Detection of measles virus antigen in human leukocyte by immunofluorescence. Arch Gesamte Virusforsch 44:323-329

18. Whittle HC, Dossetor J, Oduloju A, Bryceson ADM, Greenwood BM 1978 Cell-mediated immunity during natural measles infection. J Clin Invest 62:678-684

19. McFarland HF 1974 The effect of measles virus infection on $T$ and $B$ lymphocytes in the mouse. I. Suppression of helper cell activity. J Immunol 113:1978-1983

20. Peiton BK, Winsomehylton, Denman AM 1982 Selective immuno-suppressive effects of measles virus infection. Clin Exp Immunol 47:19-26

21. Damle NK and Gupta $S 1982$ Functionally and phenotypically distinct human $T$ lymphocyte subpopulations respond against non- $T$ cells and activated $T$ cells in AMLR. Scand J Immunol 16:59-68 